\title{
Trametes versicolor growth and laccase induction with by-products of pulp and paper industry
}

\author{
Ana Maria Rebelo Barreto Xavier* \\ Departamento de Química \\ Universidade de Aveiro \\ Campos Universitário de Santiago \\ 3810-193 Aveiro, Portugal \\ Tel: 351234370716 \\ Fax: 351234370084 \\ E-mail: abx@dq.ua.pt
Ana Paula Mora Tavares
Departamento de Química
Universidade de Aveiro
Campos Universitário de Santiago
3810-193 Aveiro, Portugal
Tel: 351225081686
Fax: 351225081674
E-mail: pdo05006@fe.up.pt

\section{Rita Ferreira}
Departamento de Química Universidade de Aveiro
Campos Universitário de Santiago
3810-193 Aveiro, Portugal \\ E-mail: rmferreira@fade.up.pt \\ Francisco Amado \\ Departamento de Química \\ Universidade de Aveiro \\ Campos Universitário de Santiago \\ 3810-193 Aveiro, Portugal \\ Tel: 351234370700 \\ Fax +351234370084 \\ E-mail: famado@dq.ua.pt
}

Financial support: The authors acknowledge Fundação para Ciência e Tecnologia (FCT-Portugal), for Project (POCTI/EQU/48489/2002) and A.P.M. Tavares Doctorate Scholarship (SFRH/BD/6606/2001).

Keywords: inducers, laccase, pulp and paper by-products, Trametes versicolor.

$\begin{array}{ll}\text { Abbreviations: } & \text { DNS: Dinitrosalicylic } \\ & \text { TDM: Trametes Defined Medium } \\ & \text { TaK: Tien and Kirk }\end{array}$

The cultivation of Trametes versicolor for laccase production and cell growth were strongly dependent on experimental conditions namely physical and chemical parameters as well as nutrient availability and inducer stimulation. Biomass growth was compared for a rich medium and for a defined medium in two different temperatures. The best temperature was $28^{\circ} \mathrm{C}$ and the maximum specific growth rates were $\mu_{\max }=0.083 \mathrm{~h}^{-1}$ for the rich medium and $\mu_{\max }=0.043 \mathrm{~h}^{-1}$ for the defined medium. It was clearly shown that laccase production is not associated with cell growth, indicating that this ligninolytic enzyme must be produced in the defined medium by a secondary metabolism. In order to obtain laccase induction, addition of solid lignin, lignosulphonates, veratryl alcohol, xylidine and ethanol was tested at different concentrations. To optimise laccase activity, the combined effect of inducer addition and simultaneously glucose suppression was studied. The best result for laccase induction $(1240 \mathrm{U} / \mathrm{L})$ was obtained with solid lignin, a by-product of pulp and paper industry and the higher laccase activity attained (1583 U/L) was obtained with the combined effect of xylidine addition and glucose suppression.

*Corresponding author 


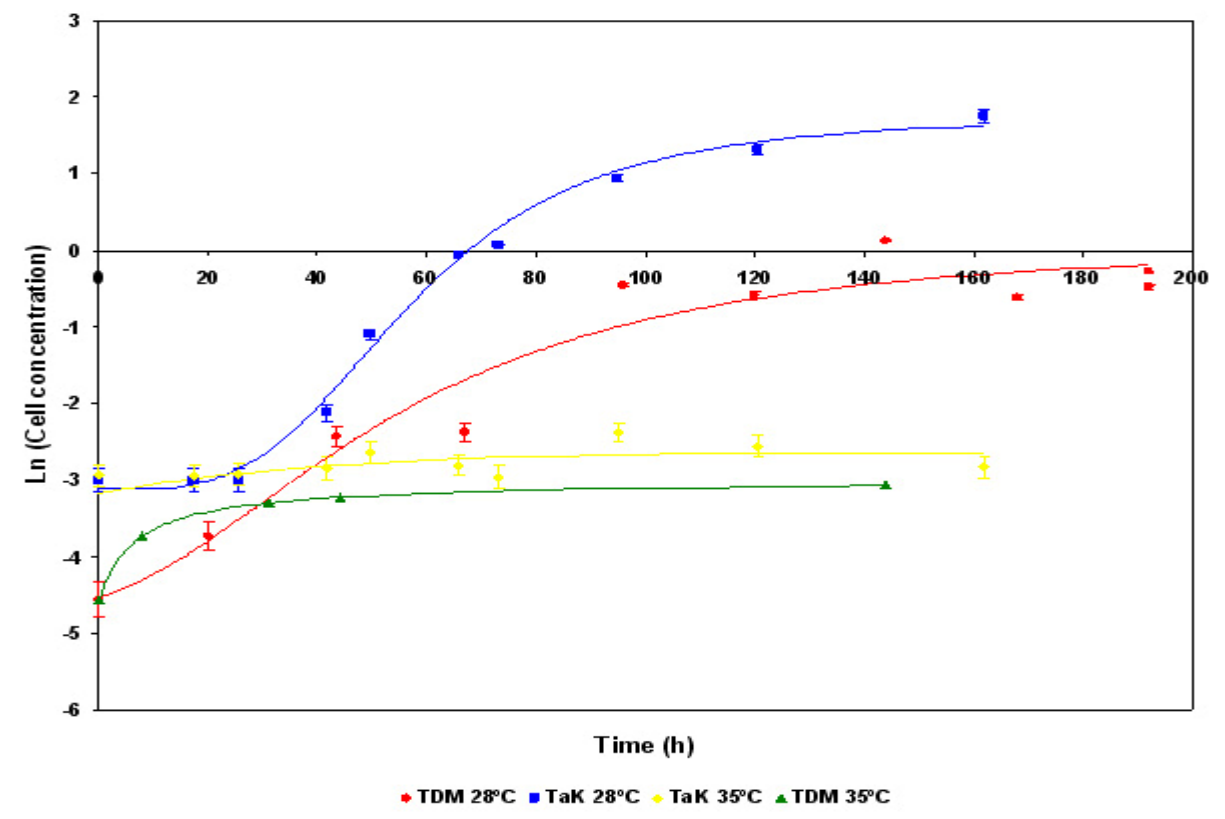

Figure 1. Growth curves for Trametes versicolor in TaK and TDM media at 28 and $35^{\circ} \mathrm{C}$ and maximum growth rates for $28^{\circ} \mathrm{C}$.

Lignin is the second most abundant natural polymer and forms a matrix surrounding the cellulose, the most abundant biopolymer. Since this encrusting matrix significantly retards microbial depolymerisation of cellulose, the degradation of lignin is a significant step in the global carbon cycle. Furthermore the presence of this intractable polymer is an obstacle to the efficient utilisation of cellulose in a wide range of industrial processes (Gold and Alic, 1993).

Basidiomycetes white-rot fungi are responsible for the most extensive biodegradation of lignin ( $\mathrm{Wu}$ et al. 2005). They have a powerful extracellular enzymatic complex, able to depolymerize this aromatic polymer into lower molecular weight compounds (Bajpai, 2004). Metabolic activity and cell growth depend on environmental conditions and specific mechanisms of enzymatic regulation, which are very important for enzymatic production. Higher fungi are heterotrophic and sessile organisms that need to excrete digestive enzymes for absorption of organic materials as a way of surviving to environmental variations. These variations constitute one or more of a multitude of environmental signals that induce specific changes in growth and development patterns as a fungus response (Read, 1994). Degradation of lignin and, more specifically, the regulation of the production of individual ligninolytic enzymes, is a complex phenomenon (Liers et al. 2006) that needs to be studied, in order to find out the correct way to obtain efficient biotechnological applications. Biochemistry and molecular genetics of lignin biodegradation have been extensively researched in recent years. Phanerochaete fungus (Highley and Dashek, 1998; Wang et al. 2004) and T. versicolor is also very studied (Cullen, 1997).

T. versicolor is a basidiomycete that produces three ligninolytic enzymes and it has an efficient degradation capacity of lignin, polycyclic aromatic hydrocarbons, a polychlorinated biphenyl mixture and a number of synthetic dyes (Tanaka et al. 1999; Novotný et al. 2004). Induction of ligninolytic enzymes expression and activity increases have been reported for copper (Collins and Dobson, 1997), xylidine (Rancaño et al. 2003), veratryl alcohol (Dekker and Barbosa, 2001) and a phenolic mixture (Tavares et al. 2005). However more work must be made to define the best experimental methodology for getting an optimal ligninolytic activity. $T$. versicolor or its enzymes have been reported to deligninify and to bleach kraft pulp (Archibald et al. 1997; Tavares et al. 2004; Gamelas et al. 2005) and also to efficiently dechlorinate and decolourise bleach kraft pulp effluents (Selvam et al. 2002), presenting a good potential to be the base of new environmental friendly technologies for pulp and paper industry. Recently several works are being done to search specific mechanisms of enzymatic lignin oxidation by each ligninolytic enzyme particularly by laccase (Castro et al. 2003). After determining correct oxidative mechanisms industrial biocatalyses can be utilised on a wide type of applications. $T$. versicolor cultures or separated ligninolytic enzymes can also be used as biocatalysts on other different industrial 
Table 1. Effect of inducers concentration on maximum laccase production by Trametes versicolor in TDM medium.

\begin{tabular}{|c|c|c|c|c|}
\hline \multirow{2}{*}{ Inducer concentration } & \multicolumn{4}{|c|}{ Maximum laccase activity (U/L) } \\
\cline { 2 - 5 } & Xylidine & Veratryl alcohol & Ligninosulphonates & Solid lign \\
\hline $10 \mu \mathrm{M}$ & 573 & - & - & - \\
\hline $15 \mu \mathrm{M}$ & 912 & - & - & - \\
\hline $30 \mu \mathrm{M}$ & 1583 & - & - & - \\
\hline $50 \mu \mathrm{M}$ & 1040 & - & - & - \\
\hline $0.050 \mathrm{mM}$ & - & 47 & - & - \\
\hline $1 \mathrm{mM}$ & - & 79 & - & - \\
\hline $2 \mathrm{mM}$ & - & $\mathbf{3 4 5}$ & - & - \\
\hline $4 \mathrm{mM}$ & - & 33 & 192 & - \\
\hline $0.034 \mathrm{~g} / \mathrm{L}$ & - & - & 224 & - \\
\hline $0.086 \mathrm{~g} / \mathrm{L}$ & - & - & $\mathbf{2 7 0}$ & - \\
\hline $0.17 \mathrm{~g} / \mathrm{L}$ & - & - & 148 & 870 \\
\hline $0.34 \mathrm{~g} / \mathrm{L}$ & - & - & - & 985 \\
\hline $0.04 \mathrm{~g} / \mathrm{L}$ & - & - & - & $\mathbf{1 2 4 0}$ \\
\hline $0.2 \mathrm{~g} / \mathrm{L}$ & - & - & - & 912 \\
\hline $0.4 \mathrm{~g} / \mathrm{L}$ & - & - & - & - \\
\hline $2.0 \mathrm{~g} / \mathrm{L}$ & - & - & & - \\
\hline
\end{tabular}

processes namely for decolourisation of industrial dyes (Swamy and Ramsay, 1999; Amaral et al. 2004; Chander et al. 2004; Liu et al. 2004) and for waste-water treatments (Modi et al. 1998).

Large-scale production of $T$. versicolor or its ligninolytic enzymes would be very interesting for the oxidation of ligninocelulosic renewable materials. Selection of experimental conditions providing increasing ligninolytic enzymes production, more than fungi growth, is very important for industrial applications and a few studies have been done to find a good experimental strategy (Nowak et al. 1998). From a practical standpoint, proposed biotechnological applications will depend on a better understanding and control of the nutritional regulation of the ligninolytic system.

In this work $T$. versicolor growth in different liquid media was quantified and growth curves are presented for different temperatures. Induction effect by pulp and paper by-products such as solid lignin and ligninosulphonates is studied and compared to those presented by different reported inducers. Glucose suppression is also analysed in order to improve laccase production or activity and effect of combination of both, inducers addition and also glucose suppression, is evaluated for laccase industrial applications.

\section{MATERIALS AND METHODS}

\section{Microorganism}

The fungus Trametes versicolor was obtained from INETI
(Instituto Nacional de Engenharia e Tecnologia Industrial) culture collection. Stock cultures were maintained on Tien and Kirk (TaK) maintenance solid medium (Tien and Kirk, $1988)$ at $4^{\circ} \mathrm{C}$ and transferred monthly.

\section{Culture conditions for growth curves}

The growth curves were made in $500 \mathrm{~mL}$ Erlenmeyer flasks with $250 \mathrm{~mL}$ of liquid culture medium. Modified Trametes Defined Medium (TDM) (Roy and Archibald, 1993) with 9 $\mathrm{g} / \mathrm{L}$ of glucose and Tween $80(0.1 \%)$ and modified TaK medium, without agar, with $9 \mathrm{~g} / \mathrm{L}$ of glucose and Tween 80 $(0.1 \%)$ were used. The liquid cultures were incubated at temperatures of $28^{\circ} \mathrm{C}$ and $35^{\circ} \mathrm{C}$ in a rotatory shaker at 180 $\mathrm{rpm}$. Inoculation was made with $0.102 \pm 0.002 \mathrm{~g}$ of mycelium previously growth at $28^{\circ} \mathrm{C}$ in Petri plates during one week.

\section{Culture conditions for laccase production}

Enzymatic assays were made in liquid cultures transferring all the mycelium from the two Petri dishes growth during one week to $500 \mathrm{~mL}$ Erlenmeyer flasks with $250 \mathrm{~mL}$ of modified TDM. Incubation was carried out for 10 days at $28^{\circ} \mathrm{C}$ in a rotatory shaker at $180 \mathrm{rpm}$. Samples were collected every day. Different sets of experiments for laccase production were carried out:

(1) To evaluate the effect of glucose presence on the laccase induction some assays were done. The inducer 
Table 2. Effect of different inducers on laccase production by Trametes versicolor in TDM medium with glucose or glucose suppression.

\begin{tabular}{|c|c|c|c|c|c|c|c|}
\hline \multirow{2}{*}{ Inducers } & \multicolumn{3}{|c|}{ Tests with glucose } & \multicolumn{3}{|c|}{ Tests with glucose suppression } & \multirow{2}{*}{$\begin{array}{l}\text { Single effects } \\
\text { addition (U/L) }\end{array}$} \\
\hline & $\begin{array}{l}\text { Maximum laccase } \\
\text { activity (U/L) }\end{array}$ & $\begin{array}{l}\text { Laccas } \\
\text { enhance }\end{array}$ & $\begin{array}{l}\text { activity } \\
\text { nent (U/L) }\end{array}$ & $\begin{array}{c}\text { Maximum laccase } \\
\text { activity (U/L) }\end{array}$ & $\begin{array}{r}\text { Laccas } \\
\text { enhance }\end{array}$ & $\begin{array}{l}\text { ctivity } \\
\text { nt (U/L) }\end{array}$ & \\
\hline Control & $65 \pm 5$ & & & $376 \pm 15$ & & & \\
\hline Veratryl alcohol & $345 \pm 16$ & 280 & $4.3^{*}$ & $1110 \pm 43$ & 734 & $3.0^{*}$ & 721 \\
\hline Xylidine & $405 \pm 21$ & 340 & $5.2^{\star}$ & $1583 \pm 70$ & 1207 & $4.2^{\star}$ & 781 \\
\hline Lignin & $1240 \pm 62$ & 1175 & $18.1^{*}$ & $1174 \pm 58$ & 798 & $3.1^{*}$ & 1616 \\
\hline Ligninosulphonate & $270 \pm 12$ & 205 & $3.2^{*}$ & $261 \pm 13$ & -115 & - & 616 \\
\hline
\end{tabular}

*fold increase

was added after three days of inoculation and four concentrations of each inducer were tested: Technical lignin from ALCELL pulping process (Repap Enterprises Corporation Inc., Canada) $(0.04 \mathrm{~g} / \mathrm{L}, 0.20 \mathrm{~g} / \mathrm{L}, 0.40 \mathrm{~g} / \mathrm{L}$ and $2.0 \mathrm{~g} / \mathrm{L}$ ) and another by-product from pulp and paper industry, ligninosulphonates (Caima Pulp Comp., Portugal) $(0.034 \mathrm{~g} / \mathrm{L}, 0.086 \mathrm{~g} / \mathrm{L}, 0.171 \mathrm{~g} / \mathrm{L}$ and $0.34 \mathrm{~g} / \mathrm{L})$ were used as laccase inducers. Other reported inducers were also tested: veratryl alcohol $(0.050 \mathrm{mM}, 1.0 \mathrm{mM}, 2.0 \mathrm{mM}$ and 4.0 $\mathrm{mM})$; ethanol (20 and $40 \mathrm{~g} / \mathrm{L})$ and 2.5 -xylidine $(30 \mu \mathrm{M})$.

(2) Laccase induction with glucose suppression: Batch tests with glucose suppression and the same inducers at the best concentration were carried out to study the combined effect. Glucose was suppressed on the third day by transferring the mycelium, through sterile filtration, to a new TDM medium without sugar. For xylidine was employed the following concentrations: $10 \mu \mathrm{M}, 15 \mu \mathrm{M}, 30$ $\mu \mathrm{M}$ and $50 \mu \mathrm{M}$.

A control was carried out in the same conditions but without inducers and with glucose.

\section{Analytical determinations}

Laccase activity was monitored according to Ander and Messner methodology (Ander and Messner, 1998) using 2,2'-azino-bis (3-ethylbenzothiazoline-6-sulfonic acid), (ABTS) as substrate at $40^{\circ} \mathrm{C}$. The reaction mixture contained $0.4 \mathrm{mM}$ ABTS in $0.05 \mathrm{mM}$ citrate $/ 0.1 \mathrm{mM}$ phosphate buffer at $\mathrm{pH} 4.5$ and enzymatic extract in a total volume of $2000 \mu \mathrm{L}$. Oxidation of ABTS was monitored through absorbance increase at $420 \mathrm{~nm}(\varepsilon=36000 \mathrm{M}-1 \mathrm{~cm}-$ 1). One unit of enzyme activity was defined as the amount of enzyme required to oxidize $1 \mu \mathrm{M}$ of ABTS per min. The laccase activities were expressed in $\mathrm{U} / \mathrm{L}$.
Quantification of glucose concentrations in the growth media was made using the 3,5-dinitrosalicylic acid (DNS) photometric method to oxidise reducing sugars (Miller, 1959) with a standard curve for glucose.

The biomass concentration was determined by dry weight of fungal mycelium. The culture medium was vacuumfiltered through $0.45 \mu \mathrm{m}$ glass microfibre filter $(\mathrm{GF} / \mathrm{C}$, Whatman, Oxon, UK). The biomass retained was washed with distilled water and dried at $100^{\circ} \mathrm{C}$ to a constant weight.

\section{RESULTS AND DISCUSSION}

\section{Culture conditions for cell growth}

In order to study $T$. versicolor growth some liquid cultures were cultivated with modified TaK medium and modified TDM medium. Both media were modified by addition of Tween 80 , a surfactant that promotes cell wall permeability to improve extracellular enzymatic activity.

T. versicolor growth curves for modified TDM and TaK media at 28 and $35^{\circ} \mathrm{C}$ are presented in Figure 1. The results show that temperature of $35^{\circ} \mathrm{C}$ did not provide significant growth for any tested media. The best result was obtained with modified $\mathrm{TaK}$ medium at $28^{\circ} \mathrm{C}$, where the maximum specific growth rate $\left(\mu_{\max }\right)$ was $0.083 \mathrm{~h}-1$ and the maximum cell concentration was higher than $5.5 \mathrm{~g} / \mathrm{L}$. For modified TDM medium $\mu_{\max }$ was nearly two fold less, $0.043 \mathrm{~h}-1$, and the maximum cell concentration was lower than $1.2 \mathrm{~g} / \mathrm{L}$, which means a reduction of 4.5 fold. As expected, cell growth was higher in modified TaK medium (a rich one) than in modified TDM (a defined medium for ligninolytic enzymes production).

The optimal temperature for species from the same family can be slightly different, for example, to $P$. chrysosporium 
one of the first studied white rot fungi, the optimal temperature was $39^{\circ} \mathrm{C}$ (Tien and Kirk, 1988) and for $T$. versicolor it was attributed a value of $28^{\circ} \mathrm{C}$ (Carroad and Wilke, 1977). Besides temperature, the culture media composition, including carbon substrates and all micronutrients, are determinant for cell growth and for specific enzymatic production. In fact $T$. versicolor did not produce detectable concentrations of laccase (data not shown) when it was grown in very good conditions, in TaK at $28^{\circ} \mathrm{C}$ and so performing primary metabolism. Eukaryotic cells have adaptive systems that allow changing their metabolism according to physical or chemical conditions, such as media nutritional limitations or environmental stimulation.

In non-limited media, fungi primary metabolism performs specific protein synthesis associated with enzyme production and other metabolites essentially for cell growth and reproduction. Limited media conditions change metabolic pathways and nutrient depletion (nitrogen, carbon or sulphur) activates secondary metabolisms (Smedsgaard and Nielsen, 2005), which will provide specific mechanisms of protein and enzyme production for surviving in such conditions.

\section{Culture conditions for laccase production}

In order to select the best inducer concentration of solid lignin, lignosulphonates, veratryl alcohol, xylidine and ethanol, specific concentrations were studied. All the inducers tested in this work stimulated the laccase production by $T$. versicolor to a certain extended (Table 1).

Laccase activity obtained with two pulp and paper industry by-products potential inducers namely technical lignin from ALCELL pulping and ligninosulphonates from a sulphite processing of pulp are shown in Table 1. Solid lignin induction has been very high and the maximum laccase activity was obtained in the concentration of $0.40 \mathrm{~g} / \mathrm{L}(1240$ $\mathrm{U} / \mathrm{L}$ ). In this assay the inducer was not in a liquid state what means that it was a heterogeneous experiment. For ligninosulphonates the best result was obtained with an aromatic content of $170 \mathrm{~g} / \mathrm{L}$, reaching a maximum laccase activity of $270 \mathrm{U} / \mathrm{L}$. Ligninosulphonates have provided less interesting results when compared to those provided by lignin.

The effect of inducers like veratryl alcohol (Mansur et al. 1997) and 2.5-xylidine (Couto et al. 2002; Nyanhongo et al. 2002) has already been reported for stimulate laccase production. The results obtained with veratryl alcohol are presented in Table 1. Addition of all the concentrations of veratryl alcohol, even being an endogenous metabolite of white rot fungi, has induced laccase activity. The most favourable concentration for laccase production was found to be $2 \mathrm{mM}(345 \mathrm{U} / \mathrm{L})$ but results are low when compared with those obtained with solid lignin (1240 U/L). Anyway these results are in the same magnitude as those obtained with ligninosulphonates.

Results obtained with 2.5-xylidine are presented in Table 1 and they clearly show that the best concentration to induce laccase production was $30 \mu \mathrm{M}$, attaining the highest laccase activity of $1583 \mathrm{U} / \mathrm{L}$. Note that the study made with 2,5xylidine was slightly different from the others once sugar suppression has occurred at the third day.

All of these tested inducers have at least one aromatic ring and all of them improved laccase production by $T$. versicolor cultures. The results here obtained are in a different order compared to those found by Lee et al. (1999) where veratryl alcohol was the most efficient inducer. Even not being an aromatic compound, ethanol was also referred in the same work, as being an effective stimulator for laccase production. In the present work ethanol addition was also tested but such effect was not found for $T$. versicolor liquid cultures, as could be expected by traditional lethal effect of high concentrations of ethanol $(40 \mathrm{~g} / \mathrm{L})$ on microbial cultures.

The effect of different inducers on maximum laccase activity for the medium with glucose is presented in Table 2. For xylidine a new assay (medium with glucose) is presented on the same experimental conditions of the tests with the other inducers. The best result for laccase induction was obtained with solid lignin which provided a 18.1-fold increase in laccase activity in relation to control, being almost three fold higher than the best of the others. This result is economically interesting once it is a byproduct of pulp and paper industry. With ligninosulphonates laccase activity increased only 3.2-fold but possibly there is a toxicity effect on fungi and process optimisation must be performed to consider the utilization of such by-product. Contrary to what happened with ligninosulphonates, with solid lignin fungi culture did not seem to be affected by toxicity, possibly because this material is a non-soluble solid (powder), avoiding a deep contact between fungi culture and this lignin.

Experimental tests were performed for all inducers in the selected concentrations simultaneously with glucose suppression to study the combined effect of both inducer addition and glucose suppression. Results are presented in Table 2.

The comparison of the results clearly shows that the combined effect of inducer addition and carbon limitation developed different fungus behaviour for each inducer in 
study (Table 2). Definitely even without any inducer, comparing to control, it is shown that carbon limitation alone was enough to increase laccase production from 65 $\mathrm{U} / \mathrm{L}$ to $376 \mathrm{U} / \mathrm{L}$ what means an increase nearly of $311 \mathrm{U} / \mathrm{L}$. These results also show that high laccase activities only initiate at third-forth day and not during exponential growth phase (data not shown) suggesting that the fungus produces laccase by a secondary metabolism.

Solid lignin addition after carbon suppression provided a lower value of laccase activity $(1174 \mathrm{U} / \mathrm{L})$ when compared to induction without glucose suppression $(1240 \mathrm{U} / \mathrm{L})$. Although when compared to respective control with glucose suppression it is clear that solid lignin still provides a high inducer effect that corresponds to an increase of 798 $\mathrm{U} / \mathrm{L}$ of laccase activity. Anyway the combination of both effects is less effective than the sum of single ones (Table 2). Perhaps in glucose presence and simultaneously in presence of such concentration of solid lignin $T$. versicolor can activate laccase production but after glucose suppression its capacity to activate such mechanism is reduced.

Ligninosulphonates addition on glucose suppressed cultures of $T$. versicolor did not provide an increase but a decrease on laccase activity what means that in this situation no induction was detected but in opposite inhibition of laccase production was occurred. Certainly in presence of glucose, $T$. versicolor can be strong enough to tolerate this specific concentration of ligninosulphonates being effective on laccase induction. Besides that, it has the capacity of reacting to the presence of ligninosulphonates being induced and promoting laccase production. Haars and Hüttermann (1983) refer that the surface of fungal hyphae contains specific receptors for phenolic compounds and these induction mechanisms certainly could be the answer for that.

Addition of veratryl alcohol to fungus culture after glucose suppression provided more $765 \mathrm{U} / \mathrm{L}$ of laccase relatively to that one without glucose suppression. This fact shows that the combination of both effects provides a best performance $(1110 \mathrm{U} / \mathrm{L})$ than the sum of the single effects $(721 \mathrm{U} / \mathrm{L})$. For xylidine addition and considering the combined effects, the increase in laccase maximum has been the higher one rising laccase from $405 \mathrm{U} / \mathrm{L}$ to $1583 \mathrm{U} / \mathrm{L}$ corresponding to an increase of $1178 \mathrm{U} / \mathrm{L}$.

When fungi are submitted to nutrient exhaustion, like carbon limitation, they can survive for short periods using their reserve compounds but essentially if they are able to use their own potential capacities, such as activating target metabolic alternative pathways associated with new enzymatic production patterns that will allow it to change to different nutritional fonts according to environmental availabilities.
This work clearly shows that these by-products of pulp and paper industry promote large increases in laccase production that can be an experimental support for potential application of $T$. versicolor cultures on pulp and paper and textile industry, for phenolic content reduction or even for soils bioremediation.

\section{REFERENCES}

AMARAL, P.F.F.; FERNANDES, L.A.F.D.; TAVARES, A.P.M.; XAVIER, A.M.R.; CAMMAROTA, M.C.; COUTINHO, J.A.P. and COELHO, M.A.Z. Decolourization of dyes from textile wastewater by Trametes versicolor. Environmental Technology, August 2004, vol. 25, no. 11, p. 1313-1320.

ANDER, Paul and MESSNER, Kurt. Oxidation of 1hydroxybenzotriazole by laccase and lignin peroxidase. Biotechnology Techniques, March 1998, vol. 12, no. 3, p. 191-195.

ARCHIBALD, F.S.; BOURBONNAIS, R.; JURASEK, L.; PAICE, M.G. and REID, I.D. Kraft pulp bleaching and delignification by Trametes versicolor. Journal of Biotechnology, March 1997, vol. 53, no. 2-3, p. 215-236.

BAJPAI, Pratima. Biological bleaching of chemical pulps. Critical Reviews in Biotechnology, January-March 2004, vol. 24 , no. 1, p. 1-58.

CARROAD, P.A. and WILKE, C.R. Exponential growth kinetics for Polyporus versicolor and Pleurotus ostreatus in submerged culture. Applied and Environmental Microbiology, April 1977, vol. 33, no. 4, p. 871-873.

CASTRO, Ana I.R.P.; EVTUGUIN, Dmitry V. and XAVIER, Ana M.R.B. Degradation of biphenyl lignin model compounds by laccase of Trametes versicolor in the presence of 1-hydroxybenzotriazole and heteropolyanion [SiW11VO40]5-. Journal of Molecular Catalysis B: Enzymatic, April 2003, vol. 22, no. 1-2, p. 13-20.

CHANDER, M.; ARORA, D.S. and BATH, H.K. Biodecolourisation of some industrial dyes by white-rot fungi. Journal of Industrial Microbiology and Biotechnology, February 2004, vol. 31, no. 2, p. 94-97.

COLLINS, P.J. and DOBSON, A.D.W. Regulation of laccase gene transcription in Trametes versicolor. Applied and Environmental Microbiology, September 1997, vol. 63, no. 9 , p. 3444-3450.

COUTO, Susana R.; GUNDÍN, María; LORENZO, Miriam and SANROMÁN, M. Angeles. Screening of supports and inducers for laccase production by Trametes versicolor in semi-solid-state conditions. Process Biochemistry, October 2002, vol. 38 , no. 2, p. 249-255. 
CULLEN, Daniel. Recent advances on the molecular genetics of ligninolytic fungi. Journal of Biotechnology, March 1997, vol. 53, no. 2, p. 273-289.

DEKKER, Robert F.H. and BARBOSA, Aneli M. The effects of aeration and veratryl alcohol on the production of two laccases by the ascomycete Botryosphaeria sp. Enzyme and Microbial Technology, January 2001, vol. 28, no. 1, p. 81-88.

GAMELAS, Jose A.F.; TAVARES, Ana P.M.; EVTUGUIN, Dmitry V. and XAVIER, Ana M.R.B. Oxygen bleaching of kraft pulp with polyoxometalates and laccase applying a novel multi-stage process. Journal of Molecular Catalysis B: Enzymatic, June 2005, vol. 33, no. 3-6, p. 57-64.

GOLD, M.H. and ALIC, M. Molecular biology of the lignin-degrading basidiomycete Phanerochaete chrysosporium. Microbiological Reviews, September 1993, vol. 57, no. 3, p. 605-622.

HAARS, Annegret and HÜTTERMANN, Aloys. Laccase induction in the white-rot fungus Heterobasidion annosum (Fr.) Bref. (Fomes annosus Fr. Cooke). Archives of Microbiology, July 1983, vol. 134, no. 4, p. 309-313.

HIGHLEY, T.L. and DASHEK, W.V. Biotechnology in study of brown-and white-rot decay. In: BRUCE, Alan and PALFREYMAN, John eds. Forest products Biotechnology. Taylor and Francis Publishers, 1998, p. 15-36.

LEE, In-Young; JUNG, Kyung-Hee; LEE, Choong-Hwan and PARK, Young-Hoon. Enhanced production of laccase in Trametes versicolor by the addition of ethanol. Biotechnology Letters, November 1999, vol. 21, no. 11, p. 965-968.

LIERS, C.; ULLRICH, R.; STEFFEN, K.T.; HATAKKA, A. and HOFRICHTER, M. Mineralization of ${ }^{14} \mathrm{C}$-labelled synthetic lignin and extracellular enzyme activities of the wood-colonizing ascomycetes Xylaria hypoxylon and Xylaria polymorpha. Applied Microbiology and Biotechnology, January 2006, vol. 69, no. 5, p. 573-579.

LIU, Weixiao; CHAO, Yapeng; YANG, Xiuqing; BAO, Hongbo and QIAN, Shijun. Biodecolorization of azo, anthraquinonic and triphenylmethane dyes by white-rot fungi and a laccase-secreting engineered strain. Journal of Industrial Microbiology and Biotechnology, March 2004, vol. 31, no. 3, p. 127-132.

MANSUR, Mariana; SUÁREZ, Teresa; FERNÁNDEXLARREA, Juan B.; BRIZUELA, María A. and GONZÁLEZ, Aldo E. Identification of a laccase gene family in the new lignin-degrading basidiomycete CECT
20197. Applied and Environmental Microbiology, July 1997, vol. 63, no. 7, p. 2637-2646.

MILLER, Gail Lorenz. Use of dinitrosalicylic acid reagent for determination of reducing sugar. Analytical Chemistry, March 1959, vol. 31, no. 3, p. 426-428.

MODI, D.R.; CHANDRA, H. and GARG, S.K. Decolourization of bagasse-based paper mill effluent by the white-rot fungus Trametes versicolor. Bioresource Technology, October 1998, vol. 66, no. 1, p. 79-81.

NOVOTNÝ, Čeněk; SVOBODOVÁ, Kateřina; ERBANOVÁ, Pavla; CAJTHAML, Tomáš; KASINATH, Aparna; LANG, Elke and ŠAŠEK, Václav. Ligninolytic fungi in bioremediation: extracellular enzyme production and degradation rate. Soil Biology and Biochemistry, October 2004, vol. 36, no. 10, p. 1545-1551.

NOWAK, G.; MATUSZEWSKA, A. and NOWAK, M. Protein secretion and oxidase activities in idiophasic cultures of Trametes versicolor. In: 7th International Conference of Biotechnology in the Pulp and Paper Industry $\left(16^{\text {th }}-19^{\text {th }}\right.$ June, 1998 , Vancouver, Canada). p. B131-134.

NYANHONGO, G.S.; GOMES, J.; GÜBITZ, G.; ZVAUYA, R.; READ, J.S. and STEINER, W. Production of laccase by a newly isolated strain of Trametes modesta. Bioresource Technology, September 2002, vol. 84, no. 3, p. 259-263.

RANCAÑO, Gonzalo; LORENZO, Miriam; MOLARES, Norma; RODRIGUEZ COUTO, Susana and SANROMÁN, M. Angeles. Production of laccase by Trametes versicolor in an airlift fermentor. Process Biochemistry, December 2003, vol. 39, no. 4, p. 467-473.

READ, N.D. Cellular nature and multicellular morphogenesis of higher fungi. In: INGRAM, D.S. and HUDSON, A. eds. Shape and form in plants and fungi. The Linnean Society of London, Academic Press, 1994, p. 251269.

ROY, Brian and ARCHIBALD, Frederick. Effects of kraft Pulp and Lignin on Trametes versicolor Carbon Metabolism. Applied and Environmental Microbiology, June 1993, vol. 59, no. 6, p. 1855-1863.

SELVAM, K.; SWAMINATHAN, K.; SONG, M.H. and CHAE, K.S. Biological treatment of a pulp and paper industry effluent by Fomes lividus and Trametes versicolor. World Journal of Microbiology and Biotechnology, August 2002, vol. 18, no. 6, p. 523-526.

SMEDSGAARD, Jørn and NIELSEN, Jens. Metabolite profiling of fungi and yeast: From phenotype to metabolome by MS and informatics Source. Journal of Experimental Botany, January 2005, vol. 56, no. 410, p. 273-286. 
SWAMY, J. and RAMSAY, J.A. The evaluation of white rot fungi in the decolouration of textile dyes. Enzyme and Microbial Technology, February 1999, vol. 24, no. 3-4, p. 130-137.

TANAKA, Hiromi; ITAKURA, Shuji and ENOKI, Akio. Hydroxyl radical generation by an extracellular lowmolecular-weight substance and phenol oxidase activity during wood degradation by the white-rot basidiomycete Trametes versicolor. Journal of Biotechnology, September 1999, vol. 75, no. 1, p. 57-70.

TAVARES, Ana P.M.; GAMELAS, Jose A.F.; GASPAR, Armindo R; EVTUGUIN, Dmitry V. and XAVIER, Ana M.R.B. A novel approach for the oxidative catalysis employing polyoxometalates-laccase system: application to the oxygen bleaching of kraft pulp. Catalysis Communication, September 2004, vol. 5, no. 9, p. 485-489.

TAVARES, A.P.M.; COELHO, M.A.Z.; COUTINHO, J.A.P. and XAVIER, A.M.R.B. Laccase improvement in submerged cultivation, induced production and kinetic modelling. Journal of Chemical Technology and Biotechnology, June 2005, vol. 80, no. 6, p. 669-676.

TIEN, Ming and KIRK, T. Kent. Lignin Peroxidase of Phanerochaete chrysosporium. Methods in Enzymology, 1988, vol. 161, p. 238-249.

WANG, Haikuan; LU, Fuping; SUN, Yafan and DU, Lianxiang. Heterologous expression of lignin peroxidase of Phanerochaete chrysosporium in Pichia methanolica. Biotechnology Letters, October 2004, vol. 26, no. 20, p. 1569-1573.

WU, Juan; XIAO, Ya-Zhong and YU, Han-Qing. Degradation of lignin in pulp mill wastewaters by white-rot fungi on biofilm. Bioresource Technology, August 2005, vol. 96 , no. 12 , p. 1357-1363. 